\title{
Responsible CSR Communications: Avoid "Washing" Your Corporate Social Responsibility (CSR) Reports and Messages
}

\author{
Paula Bernardino \\ Credibility Institute
}

With the rise of Corporate Social Responsibility (CSR) reporting, questions have emerged regarding its true utility; CSR reports may more closely resemble marketing materials than financial statements as much of the data companies provide can be cherry picked. For example in 2011, only 20\% of S\&P 500 companies published CSR reports vs 85\% in 2017 and 90\% in 2019.

Why is this relevant for communicators? Because the responsibility of producing and promoting CSR reports very often falls under the responsibility of the corporate communications team. How to avoid "CSRwashing" and all the other "washing" incidents - green-washing, blue-washing, rainbow-washing, veganwashing,...? How to focus on portraying the organization as a truly and authentic dedicated corporate citizen?

In-depth interviews with 15 senior communication practitioners in Canada helped identify what are "authentic" and "responsible" communications in the CSR space: using facts and testimonials, being transparent, showing authenticity as well as demonstrate the clear alignment with the organization's purpose.

Keywords: corporate social responsibility, CSR, greenwashing, authenticity, credibility, sustainability reporting, corporate reputation, corporate communications, stakeholder relationship, corporate citizenship, ESG, purpose

\section{INTRODUCTION}

With the rise of Corporate Social Responsibility (CSR) reporting, questions have emerged regarding its true utility; CSR reports may more closely resemble marketing materials than financial statements as much of the data companies provide can be cherry picked. For example in 2011 , only $20 \%$ of S\&P 500 companies published CSR reports vs 85\% in 2017 and 90\% in 2019 (Governance \& Accountability Institute, Inc., 2020). These reports are also sometimes titled as corporate responsibility, citizenship, or ESG reports (Environmental, Social, Governance), adding to the existing confusion and lack of coherence.

As beautifully stated in a Think Advisor article published in 2019, "The growth of ESG investing is now in the trillions, but a standardized - and accurate - measurement of how companies live up to social responsibility remains elusive.” (Drum \& Ashton, 2019) 
Why is this relevant for communicators? Because the responsibility of producing and promoting CSR reports very often falls under the responsibility of the corporate communications team.

How to avoid "CSR- washing" and all the other "washing" incidents - green-washing, blue-washing, rainbow-washing, vegan-washing,...? How to focus on portraying the organization as a truly and authentic dedicated corporate citizen?

Responses to these questions reflect the value for communication professionals' role:

- advocate for the profession;

- represent best practices;

- focus on insights and results;

- position communication as a strategic function that has impact on return- on- investment;

- demonstrate the business value of communication;

- and live by a code of ethics.

\section{RESEARCH PROBLEM AND QUESTIONS}

(1) What is "washing" is the CSR space?

(2) How can you be a responsible CSR communicator?

(3) What are examples of best practices?

\section{LITERATURE REVIEW}

\section{The Rising Pressure for Good Corporate Citizenship}

The era of corporations "winning for shareholders" is coming to an end. To survive and remain sustainable, corporations need to revise their mode of operations and reflect on how they can and should create a positive impact for society and the environment.

Corporations were destabilized with BlackRock Chairman Larry Fink's 2019 letter to CEOs on the importance of purpose: "Purpose and Profit: An Inextricable Link" (BlackRock, 2019) where he wrote "Purpose is not a mere tagline or marketing campaign; it is a company's fundamental reason for being what it does every day to create value for its stakeholders. Purpose is not the sole pursuit of profits but the animating force for achieving them." Fink has expressed that his investment firm is increasingly integrating ESG issues into the investment decisions. He stated, "a company's ability to manage environment, social and governance matters demonstrates the leadership and good governance that is so essential to sustainable growth," (Atkins, 2020)

It was interesting then in August 2019 when news came from the influential Business Roundtable that "America's CEOs seek a new purpose for the corporation," (Murray, 2019). After decades of explicitly putting shareholders first, the powerful group expressed wanting to redefine its mission given the atmosphere of widening economic inequality and deepening distrust of business. Their updated definition of the purpose of a corporation expanded the definition to include a focus on other stakeholders than investors and includes commitments to customers, employees, suppliers, communities and shareholders. This new statement is different from the original definition that followed Professor Milton Friedman doctrine from the 1970s which said "... the paramount duty of management and of boards of directors is to the corporation's stockholders," (Governance \& Accountability Institute, 2019). Hence very different from that approach and embraces the idea that stakeholders (and shareholders) really do matter. Through the forum of the Business Roundtable, member CEOs claimed their commitment to stakeholder relations and communicating the importance of corporate sustainability, responsibility, citizenship and accountability.

It is interesting to know that the Certified General Accountants' Association of Canada view CSR as "a company's commitment to operating in an economically, socially, and environmentally sustainable manner, while recognizing the interests of its stakeholders, including investors, customers, employees, business partners, local communities, the environment, and society at large," (Jande, n.d.) 
It seems clear that in today's business environment, management cannot deny its obligations to its stakeholders. "The stakeholder concept suggests that the managers of businesses should take into account their responsibilities to different groups when making decisions and by doing so, businesses can benefit significantly from cooperating with stakeholder groups," argues Mari Kooskora in her paper published in Ethical and Environment Competence for Sustainable Development in 2010. "Through stakeholder pressure, corporations will implement concerns related to product safety, truth in advertising, workplace safety and environmental problems. Therefore, in theory, a business should take into consideration all the different stakeholders it influences and set up a two-way communication with them. However, as in practice it is often difficult if not impossible to give the same amount of attention to all stakeholder groups," (Kooskora, 2010). The stakeholder concept in CSR communications is an important opportunity for communication practitioners to shine their expertise and show the value they can bring to the organization by tackling stakeholder management.

According to the Reputation Institute (2018), although the initial focus on protecting the environment and advancing critical social issues remain critical, "companies need to serve a greater social purpose, make a positive impact on society, and show that they are fiscally responsible for the long haul". The Reputation Institute defines corporate responsibility as a measure of three reputation drivers: citizenship, governance and workplace. These are three aspects where communication practitioners are actively involved in and can again play a major role in their organizations.

What else is driving this change? Public interest in corporate responsibility is unusually high. In addition to an increase in CSR reporting as indicated in the introduction with $90 \%$ of S\&P 500 companies publishing CSR reports in 2019, the "popularity" for "sustainability communications" or "CSR communications" is rising. A quick Google search with these two specific words will show a growing list of positions with this title, such as a job posting example from Tiffany \& Co in December 2019: Manager - Sustainability Communications. The description indicates the person will serve as "the connective tissue between teams to help establish Tiffany's reputation as a leader in sustainability, helping to share about our long-standing, rigorous sustainability approach to consumers, employees and the general public." It is also interesting that this manager is asked to "drive sustainability communications in partnership with marketing and communications functions as a central point of contact between departments."

Hence, in a move to look transparent, an increased number of companies are hiring for specific CSR and sustainability communications and putting out sustainability reports. But these reports have to be authentic; otherwise stakeholders will call out these companies for using their corporate social responsibility actions and sustainability initiatives for marketing purposes only. An "authentic" CSR or sustainability report means showcasing the good actions and initiatives, but followed by a reflection discussing where improvements can/will be made, addressing mistakes and misses, identifying risks not being addressed (yet!) and what measures will be tackled by the company in the short and long term future.

According to Global Giving (2019) “corporate social responsibility isn't just good ethics, it's good business. After all, $92 \%$ of consumers have more positive views toward companies that make an effort to protect the environment and support social initiatives." Therefore, a CSR report is a formal document that assesses how a company's operations affect the world around them. The report can cover economic, environmental and/or social impacts depending on what the company does. A good CSR report can improve a company's image and warn company leaders of upcoming risks and issues. According to Truesdale in Corporate Citizenship (2018) "the best corporate reporting addresses not just what the corporation is doing but the impact that its action are having." And he adds that companies just not simply list their actions but also offer thoughtfulness about its impacts.

It is important then to introduce here the concept of 'greenwashing' which can be generally described as "the practice of only paying lip service to environmental, social and governance (ESG) factors with token gestures. In practice, greenwashing occurs when an organization presents misleading or inconsistent information that makes it appear more environmentally responsible than it is," (Styles, 2020). The term "washing" has expanded. In addition to greenwashing, it is common to hear "rainbow-washing", "feminism-washing", "social-washing,..." This represents a crucial opportunity for communication practitioners to play a role ensuring responsible communications. "One significant mistake to avoid is the 
temptation to let exuberant communications teams publish anything that they think will resonate with ESGinterested stakeholders, without strategic coordination, prioritization and materiality assessment," (Styles, 2020).

Because of bad corporate behaviours in the past, many are sceptical whenever corporations communicate doing or wanting to do good. Which was not surprising to see an from Corporate Knights right after the announcement from the Business Roundtable CEOs in August 2019: "Dear Business Roundtable CEOs: Some tips on avoiding purpose-washing" (Heaps \& Vasil, 2019). The public is watching and the message to corporations is clear "Be authentic in your actions!" and "Walk the talk!".

Benevity's paper on Building your ESG profile through your CSR program states "employees and customers expect transparency and accountability, and companies are recognizing the need to make their initiatives authentic and part of the fabric of the company's culture," (Benevity, 2020).

An interesting observation is 'secret sustainability' (Coburn, 2019) on the rise, as companies are reluctant to talk about their ecological credentials to avoid questioning and backlash. Why would companies spearheading sustainable practices not publicise their good work? According to Professor Steve Evans, director of research in industrial sustainability at Cambridge University's Institute for Manufacturing "companies and consumers seem unable to accept that sustainability does not have to cost more to create an equally good product. Apparently, we simply cannot believe that a business can be equally or more profitable while reducing its environmental harm," (Cambridge Institute for Sustainability Leadership, 2020).

This turmoil will calm down... CEOs and executive team members will get it that the era of corporations "winning for shareholders" is coming to an end.

The pressure from investors and board members demanding more action on ESG - Environmental, Social and Governance will be key as "ESG is quickly rising to the top of boardroom agendas," (Banham, 2019).

This story is currently unfolding... stay tuned!

\section{Opportunity for Communication Practitioners}

Are communication professionals ready and equipped to communicate CSR and sustainability content in a responsible way? A recent article in the Canadian Institute of Mining (CIM) Magazine (Rolfe, February 2020) had an insightful title: "Has sustainability reporting become unsustainable?". "Environmental, social and corporate governance rating is a burgeoning industry, and not without its growing pains," states the article. The pain point is all the different acronyms and standards involved in CSR and sustainability reporting: ESG, GRI principles, SASB, TCFD, SDGs... and these are not only related to the mining industry but to any industry and organization producing CSR or sustainability reports. All this confusion and frustration are due to the fact that there is no standardized guide for regulated ESG disclosure for publicly traded companies to follow. Hence, companies are left selecting between the different reporting frameworks.

Once a CSR or sustainability report is produced, the content must tell a clear story of where the organization is going from an ESG standpoint: what are the environmental, social and governance aspects that are being addressed well and what are the ones that need increased efforts. And this is where communication professionals can play a role in telling this story. This reflection has to be authentic in order to be credible: address both the positive stories but also the misses.

The CIM Magazing article (Rolfe, February 2020) mentions the many reporting standards all have slightly different lenses and are intended for different audiences. "The difficulty for a company is in gauging which of the many standards provide information that is both compelling for the reader and also allow true comparisons to be made with other reporting companies," said Christian Milau, Equinox's CEO (Rolfe, February 2020). This again, is where communication professionals can help in crafting those different messages for different audiences.

In a 2008 paper published in Critical Sociology, Subhabrata Bobby Banerjee explored the relationship between business and society. "Whereas the primary relationship between business and society has been and continues to be an economic one, rising public concern about the social and environmental impacts of 
economic growth and increased legislation in areas of social welfare and environmental protection have led many corporations to assess the social and environmental impacts of their business activity,". She also mentions in this paper a study that found that the biggest CEO raises were linked to the largest layoffs. "Of course all of these 50 companies produce slick, glossy corporate social responsibility reports annually. And the argument that this is somehow good for the global economy begs the question: whose globe and whose

economy?" Something for communication practitioners to think about when producing corporate social responsibility reports - is the information being communicated in the corporate social responsibility report showing authenticity and transparency?

According to an article from Dr. Hua Jiang, associate professor in S.I. Newhouse School of Public Communications at Syracuse University and published by the Institute for Public Relations (2020) "when CSR communication is not effective or reflective of a company's CSR activities, stakeholders may perceive a high level of hypocrisy (Kim \& Ferguson, 2018). The presence of informativeness, personal relevance, transparency, consistency, and factual tone in CSR communication mitigates stakeholders' scepticism," (Kim, 2019).

Anne Ellerup Nielsen and Christa Thomsen conducted a research for the Aarhus School of Business in Denmark (2007) with which they seeked to analyse and discuss what organizations say and how they say it when CSR. They were hoping to find a formula for implementing and communicating aspects of responsibility to their stakeholders. However, as there is no established framework, only guidelines, for how to communicate consistently about CSR, they found many organizations are somewhat unprepared. "The lack of a common understanding and terminology in the area of CSR has made it difficult for organizations to develop consistent strategies for reporting on CSR, which have caused the communication from many organizations to be rather inconsistent".

In an article published in Business and Society Review in 2005, Carmen Valor, associate teacher at Universidad San Pablo-CEU, discusses the concept of "managerial capture". She explains that when stakeholders have made it clear that companies

must achieve social and environmental performances, managers have shown their reluctance to sacrifice profits in favor of the common good. "This reluctance, labelled as "managerial capture," has turned the discourse of CSR into PR exercises rather than endeavouring to rethink and reshape corporate internal management. The risk of managerial capture may have been aggravated by the tendency of justifying CSR on economic grounds". This represents another interesting and important opportunity for communication practitioners to show their value and do responsible CSR communications and avoid turning it into the "PR exercise" Valor mentions.

A white paper from Think Parallax (2019) - The formula for communicating ESG - discusses how "strong storytelling around ESG initiatives can help companies create clarity in a way which amplifies social and environmental impact while satisfying and even exceeding demands for increased transparency". The paper offers a communication formula for sustainability storytelling and it's a good start. It argues strong storytelling around ESG initiatives can help companies create clarity, while amplifying social and environmental impact while also addressing transparency. "Corporate sustainability isn't just about strategy, it's also about storytelling," and communication practitioners have the expertise to tackle the corporate narrative.

The issues businesses face, and in turn need to communicate, are vast and complex. There's increasing pressure for businesses to communicate its actions, vision and impact in a simplified manner that engages key audiences and demonstrates integrity and leadership. Are communication professionals ready to navigate through all these CSR and sustainability acronyms and disparate reporting guides? And perhaps turn CSR and sustainability reports into communication tools for authentic reflections and conversations?

\section{METHODOLOGY}

To further the reflection on "what is responsible CSR communications" and if communication practitioners are grasping what it means, 15 in-depth 30-minute interviews with senior communication 
practitioners in Canada with at least 15 years of experience in the field were conducted in July 2020 via telephone or videoconference with Zoom.

The first interview was held on July 3, 2020 and the last was conducted July 24, 2020. Nine interviews were done with communication practitioners in the private sector, mainly working in global companies, while two interviewees were from the non-profit sector, two others from educational institutes and the remainder two were from small businesses. One practitioner from the United States and another from the United Kingdom were also interviewed for comparison purposes, as well as an ESG consultant to get the perspective from a different angle. All participants taking part in the individual in-depth interviews gave the consent orally. The consent information was read to participants before the interview questions began and participants were asked if they agreed or not.

In the recruitment phase, identities were kept anonymous since potential participants were always contacted individually. Furthermore, in-depth interviews were conducted individually, therefore participants did not know about each other nor did the investigator ever name participants to other participants during interviews. In the data collection phase the investigator noted participants' identity to ensure the right data was collected for the right participant. In the data storage phase, notes collected by the investigator included participants' identities to ensure the right data was collected for the right participant but only the investigator had access to this data, therefore ensuring the anonymity of all participants in this stage of research.

\section{RESULTS}

\section{In-Depth Interviews}

In-depth telephone interviews with 15 senior communication practitioners were conducted between July 3 and July 24, 2020. Nine interviews were done with communication practitioners in the private sector, mainly working in global companies, while two interviewees were from the non-profit sector, two others from educational institutes and the remainder two were from small businesses. One practitioner from the United States and another from the United Kingdom were also interviewed for comparison purposes, as well as an ESG consultant to get the perspective from a different angle.

Questions 1 and 2 were asked for statistical purposes. Answers to Question 1 How long have you been in the communications field? ranged from 17 years to 30 years, with 25 years of experience being the average. Answers to Question 2 How long have you been working at your current organization? ranged from one year to 20 years.

Question 3 assessed whether the organization created and/or published a CSR or sustainability report. If the answer was yes, participants were asked to describe the process - Who gathers the content? Who creates the content? And what happens once the report is produced? All respondents from the global companies in the private sector answered yes and were involved with their team in the creation of the CSR report. All expressed the importance of including metrics in the report and show the progression of targets that were identified. Interestingly, those in the non-profit sector as well as in the education industry also reported publishing a report but call it an "impact report", focused on demonstrated their organizations positive actions in their respective communities, closely aligned with the mission of the organization.

Part B of Question 3 was then to assess if there were additional CSR or sustainability communications in addition to the report, and if so, to describe these and explain how the communications team is involved. All communication practitioners in the private sector also have an annual communication plan to further increase the awareness of their CSR initiatives in addition to the report. Some communications teams work on publishing monthly CSR stories both internally and externally, others do it quarterly through articles or town halls.

A note must be made here that compared to the findings from the Governance \& Accountability Institute that $90 \%$ of S\&P 500 companies published CSR reports in 2019 , there is a gap in Canada with only about half of S\&P/TSX companies doing it (Kaplan, 2019)..

Answer to Question 4 Have you noticed an increased interest in CSR and/or sustainability communications in the last two years? What about in the last five years? was an unanimous "yes". 
The purpose of Question 5 Given all the acronyms and different standards when talking about CSR and sustainability i.e. ESG, GRI, SASB, SDGs, TCFD... how do you keep up with these? How much time do you dedicate to understand these technical aspects? was simply to assess how deeply the communication practitioners are aware of trends with sustainability reporting. This question was not related for those in small businesses, non-profit or in education. Those in the private sector were aware of these acronyms, which represent different standards for reporting frameworks. "You don't need to be an expert, but you need to know the frameworks," said a participant.

Answers to Question 6 When you communicate and promote your organization's CSR and sustainability efforts, do you worry about "washing" any aspect and are you concerned of being accused of "greenwashing" or any other type of "washing"? How do you avoid it? demonstrated communication practitioners understand the meaning of "washing" CSR communications and clearly expressed how to avoid it. Answered included "be attentive to authenticity and justifiable messages. Show humility and be humble," and "what is important is to be transparent instead of putting a marketing spin to it; not be afraid to mention the issues," as well as "a balance between acknowledging current aspects vs sounding authentic," and "use data that is accurate and comparable to previous years or other benchmarks". Hence, they key answers to Question 6 were: facts, transparency and authenticity.

Participants were then asked Question 7 When thinking about your CSR and sustainability communications, what does a "responsible communication" mean to you? and again main answers heard were: authenticity, transparency and facts.

Questions 8 led participants to further think about authenticity: How do you ensure your CSR and sustainability communications are "authentic"? "Connect your CSR communications to the organization's mission and values. It has to make sense. The alignment must be clear," said a participant. Another participant also mentioned having to align with business practices. "Walk the talk" was also mentioned by two participants.

Most answers to Question 9 What role should the communication function play when communicating CSR and sustainability reports and other CSR and sustainability messages? demonstrated communications practitioners believe communications teams have a huge role to play to push an organization's CSR and sustainability journey. "It's the communication function that maintains CSR alive here; without the communication team there weren't be any CSR," said a participant. "The communication team plays the important role of being the internal ambassador for CSR and get internal stakeholders interested with customized messages to the different internal groups," said another participant. And finally "the communication team can help ensure accuracy, reliability, completeness, balanced and comparability content." It is interesting that for practitioners in the non-profit sector, their answers to this question focused on using the content for storytelling to showcase what their organizations do and the impact they have.

Question 10 got participants to reflect on who are the main stakeholders interested in your organization's CSR and sustainability communications? It is clear with their answers and how quickly they responded that they are aware of who their main stakeholders are. For communication practitioners in the private sector, all mentioned employees and customers. Some also mentioned government, investors and suppliers.

Finally, Question 11 Do you think your CSR/sustainability efforts can be a tool/advantage for talent recruitment? prompted participants to remember another important stakeholder they had not identified in Question 10: potential new applicants and future employees. Many communication practitioners discussed how human resources have asked for CSR content to include in job descriptions and on the career pages online. "It's a way to attract younger people as they want to work for responsible companies," said a participant. Another participant had a different view but with the same conclusion that it's important: "the company does not offer anything new or anything different with its CSR program compared to other companies, so it's not really an advantage, but it would be a disadvantage if it didn't have CSR initiatives."

Overall, the responses demonstrate communication practitioners grasping the crucial role the communication function can play in delivering "responsible CSR communications" and how to do it, and understanding there are many different stakeholders interested by a company's CSR and sustainability initiatives and programs. 
In their article The Future of CSR is Corporate Activism, Dr. Ximena Hartsock and Jeb Ory argue "the notion that a for-profit business is accountable solely to shareholders is dead. Businesses that want to be profitable must meet ethical standards set by their employees and customers first," (2018). Communications practitioners in the for-profit sector that were interviewed demonstrated grasping this notion with their answers in Question 10 as they named a list of main stakeholders.

The additional interviews, the practitioner from the United States and the practitioner from the United Kingdom, yielded similar results. When discussing "responsible communication", the practitioner in the UK mentioned "have facts, show the numbers, explain the impact and include testimonials such as with employee-led stories". The practitioner in the US offered a clear answer to what role should the communication function play when communicating CSR and sustainability reports and other CSR and sustainability messages: "advocate for communicating the information publicly, ask questions and lead reflections; push for more disclosure and transparency, and translate complex language into something our publics will understand."

The interview with the ESG consultant was to get the perspective from a different angle. Her work involves advising organizations plan and create their ESG reporting strategies. She does not work directly with communication teams but does see a disconnect between teams working on reports and the communication teams. "They should be working more closely together," she said. She also notices many organizations are afraid to disclose their ESG, CSR or sustainability information. This represents an opportunity for communication practitioners and their teams to step up and help position their companies as good corporate citizens.

Interviews with communication practitioners from small companies, confirmed what Anne Ellerup Nielsen and Christa Thomsen discussed in their 2012 paper published in the Journal of Language and Communication in Business. Their analysis showed that "small-and medium-sized enterprise (SME) managers clearly have an inside-out approach to CSR, with a strong emphasis on the internal corporate culture dimension. However, SMEs and/or SME managers tend not to communicate externally about their CSR activities," (Nielsen \& Thomsen, 2012). One participant in the in-depth interview from a small business kept answering "we are too small" when asked about a CSR report or CSR communications. But ended up realizing the company's employees are indeed a main stakeholder interested and questioning social practices of the organization. Therefore, even for small businesses the need for CSR communications exists.

\section{DISCUSSION AND RECOMMENDATIONS}

Answers to the three research questions helped determine what is "responsible communications" and how communications practitioners can avoid the trap of "washing" their CSR reports and/or messages:

(RQ1) What is "washing" is the CSR space?

"Washing" occurs when the content is empty or means nothing - it's just words. "Washing" also occurs when there is missing information or no context, or when it's lies.

There are various types of "washing", with greenwashing being the most common one. But others include rainbow-washing related to companies' unauthentic actions during Pride month, feminismwashing, purpose-washing, social-washing,...

Interviews with senior communication practitioners helped identify how to avoid the trap if "washing" CSR reports and/or messages: facts, transparency and authenticity. Breaking it down, this means: use and include facts, be transparent by not only communicating the positive actions but also discussing risks and misses, and show authenticity by showing the alignment with the business mission and values.

(RQ2) How can you be a responsible CSR communicator?

Same as for RQ1: show authenticity, transparency and facts. 


\section{(RQ3) What are examples of best practices?}

What makes good CSR communications for reports: show authenticity, discuss progression, demonstrate transparency, don't omit relevant information and don't lie.

What makes good CSR communications for messages: show alignment $\&$ coherence with the business mission, show transparency \& humbleness and show authenticity with "walk the talk".

Benevity's engagement study showed that "companies whose people are deeply connected to their CSR efforts tend to have better employee retention than those that don't," (Benevity, 2020). This is another reason why communications practitioners need to give attention to CSR communications. As demonstrated with the findings from Question 11, a company's CSR initiatives and programs are getting attention from job applicants and can be an advantageous tool for talent recruitment as well as talent retention. Benevity's engagement study, which looked at more than 2 million users worldwide across 118 companies, found that "turnover was reduced by 57\% (and in some cases higher) for employees who were actively engaged in their company's corporate purpose iniatives," (Benevity, 2020). Hence, a strong CSR program is closely connected to a company's ability to attract and retain talent, which is a key factor in ESG scoring and indicator of a company's long-term financial health.

As Anne Ellerup Nielsen and Christa Thomsen present in their 2012 paper published in the Journal of Language and Communication in Business "CSR communication is defined as a process of anticipating stakeholders' expectations, articulation of CSR policy and managing different organization communication tools designed to provide true and transparent information about a company's or a brand's integration of its business operations, social and environmental concerns, and interactions with stakeholders," (Nielsen \& Thomsen, 2012).

\section{LIMITATIONS}

The generalization of this study is limited as it involved only 15 communication practitioners.

\section{FURTHER RESEARCH}

It would be useful to explore more from private sector, non-profit and education and healthcare to draw stronger patterns. And look separately at industries whose DNA is a social purpose and how it affects their mindset when thinking about their organization's corporate social responsibility.

Also more research is needed to study CSR communication as a focal concept linked to stakeholders' perceptions of corporate reputation. As Anne Ellerup Nielsen and Christa Thomsen mention in their 2012 paper published in the Journal of Language and Communication in Business "in most textbooks and anthologies, CSR communication has not been subject to research in its own right," (Nielsen \& Thomsen, 2012).

\section{CONCLUSIONS}

The literature and results from the in-depth interviews with senior communication practitioners demonstrate effective communication of a company's CSR initiatives contributes to the mutually beneficial relationships that it can develop with its internal and external stakeholders.

In order to report consistently on CSR companies need to use discourse types which represent perspectives pointing more or less in the same "direction", which means show clear alignment with the organization's mission. The future of any one company in today's society depends critically on how it is viewed by key stakeholders such as shareholders and investors, customers and consumers, employees and members of the community in which the company resides. Thus, companies need to build and nurture relationships with stakeholders, and they must know how to strategically manage and organize activities aimed at their stakeholders. Reporting is one of the activities used by companies in a strategic and instrumental manner. It makes sense to contemplate it as a corporate communications tool which helps 
companies to be judged as "legitimate" by most, if not all, of their stakeholders in order to survive and prosper. Conceived as a corporate communications tool, annual reports and other reports must focus on the organization as a whole and the task of how an organization is presented to all of its key stakeholders, both internal and external. As expressed by Nielsen and Thomsen (2007) "it is crucial to know how to report consistently on CSR," and "it is possible to communicate a strong social commitment on the one hand and take into consideration the expectations of the shareholders and of the other stakeholders on the other hand."

According to Kim (2019) "the presence of informativeness, personal relevance, transparency, consistency, and factual tone in CSR communication mitigates stakeholders' scepticism," which is reflective of what the senior communication practitioners that participated in the in-depth interviews expressed.

Not to be neglected is the positive effects effective CSR communications has on employees and internal audiences. Based on Jiang's survey results from 811 employee responses (2020), her study provides employee communication managers with the following research-based suggestions:

(1) "Corporate CSR communication should include details about a company's efforts, such as CSR commitment, motives, impact, and third-party endorsement. (informativeness)

(2) Strategic communication should tie CSR messages to stakeholders' personal life experiences and/or interests. (relevance)

(3) Transparent CSR communication should be open and balances with information about both successes and failures. (transparency)

(4) Organizations must communicate steadily about its CSR goals with their internal and external audiences. (consistency)

(5) A self-promotional tone in CSR communication should be avoided as it induces scepticism or doubts about a company's altruistic CSR motives. (factual tone)

(6) Communication practitioners and top management need to acknowledge the link between effective CSR communication and strengthened corporate reputation and design and implement corporate strategies accordingly.

(7) Organizational communication should be practiced for the purpose of motivating employees to become "brand ambassadors" on social media communicating CSR with external audiences, engaging employees in productive CSR-related work, and promoting employees' understanding of their organizations' CSR motives."

In her February 2020 article Do consumers think brand purpose is bullshit? Ali Demos, group planning director at StrawberryFrog discusses common pitfalls to avoid: claims are too generic, message is tone-deaf to the real issues customers and/or employees are facing, it lacks connection to the brand's DNA, it's "purpose-washing", it doesn't inspire employees and it doesn't get activated.

It thus comes back to what communication practitioners interviewed said: for responsible CSR communications use facts, be transparent and show authenticity.

\section{ACKNOWLEDGEMENTS}

Thank you to the Credibility Institute and its founder and President, Stéphane Prud'homme, for endorsing this study conducted in July 2020.

\section{REFERENCES}

Atkins, B. (2020, June 8). Demystifying ESG: Its History \& Current Status. Forbes Markets. Retrieved from https://www.forbes.com/sites/betsyatkins/2020/06/08/demystifying-esgits-history--currentstatus/\#2ca818062cdd.

Banerjee, S.B. (2008). Corporate Social Responsibility: The Good, the Bad and the Ugly. Critical Sociology, 34(1).

Banham, R. (2019, December 10). Board Action on ESG Needed to Ensure Long-Term Performance Gains. Forbes Insights. Retrieved from https://www.forbes.com/sites/insights- 
kpmg/2019/12/10/board-action-on-esg-needed-to-ensure-long-term-performancegains/\#713297b05542.

Benevity. (2020). How to Drive ESG Outcomes Through Your CSR Programs. Retrieved from https://info.benevity.com/rs/970-BMO-559/images/esg-ebook.pdf.

BlackRock. (2019). Larry Fink's Letter to CEOs. Retrieved from https://www.blackrock.com/corporate/investor-relations/larry-fink-ceo-letter

Cambridge Institute for Sustainability Leadership. (2020). Professor Steve Evans, director of research in industrial sustainability at Cambridge University's Institute for Manufacturing. Retrieved from https://www.cisl.cam.ac.uk/directory/dr-steve-evans

Camilleri, M.A. (2016). Corporate Citizenship and Social Responsibility Policies in the United States of America. Sustainability Accounting Management and Policy Journal.

Coburn, C. (2019, September 8). Why Industry is Going Green on the Quiet. The Guardian. Retrieved from https://www.theguardian.com/science/2019/sep/08/producers-keep-sustainable-practicessecret

Demos, A. (2020, February 3). Do consumers think brand purpose is bullshit? The Drum. Retrieved from https://www.thedrum.com/opinion/2020/02/03/do-consumers-think-brand-purpose-bullshit

Drum, P., \& Ashton, S. (2019, March 26). Is Corporate Social Responsibility Just a Potemkin Village? Think Advisor. Retrieved from https://www.thinkadvisor.com/2019/03/26/is-corporate-socialresponsibility-reporting-just-a-potemkin-village/

Global Giving. (2019, October 2). The CSR Report Checklist Every Company Needs. Retrieved from https://www.globalgiving.org/learn/csr-report

Governance \& Accountability Institute. (2019, December). Analysis of the Business Roundtable Companies' ESG Reporting Practices. Retrieved from https://www.ga-institute.com/researchreports/resource-papers/analysis-of-the-business-roundtable-companies-esg-reporting-practicesresource-paper.html

Governance \& Accountability Institute. (2020, December). 2020 Flash Report S\&P 500 - Trends on the Sustainability Reporting Practices of S\&P 500 Index Companies. Retrieved from https://www.gainstitute.com/research-reports/flash-reports/2020-sp-500-flash-report.html

Hartsock, X., \& Ory, J. (2018, July 24). The Future of CSR is Corporate Activism. Triple Pundit. Retrieved from https://www.triplepundit.com/story/2018/future-csr-corporate-activism/11566

Heaps, T., \& Vasil, A. (2019, September 6). Dear Business Roundtable CEOs: Some Tips on Avoiding Purpose-Washing. Corporate Knights. Retrieved from

https://www.corporateknights.com/channels/leadership/how-business-roundtable-can-avoidpurpose-washing-15677777/

Jande, A.A. (n.d.). CSR as a Concept Covers Many Issues

Jiang, H. (2020, February 5). Eight Best Practices for Linking CSR to Corporate Reputation. Institute for Public Relations. Retrieved from https://instituteforpr.org/eight-best-practices-for-linking-csr-tocorporate-reputation/

Kaplan, S. (2019, September 16). The Business Roundtable has Repudiated Shareholder Primacy: Where do Canada's CEOs Stand? The Globe and Mail. Retrieved from

https://www.theglobeandmail.com/business/commentary/article-the-business-roundtable-hasrepudiated-shareholder-primacy-where-does/

Kim, S. (2019). The Process Model of Corporate Social Responsibility (CSR) Communication: CSR Communication and its Relationship with Consumers' CSR Knowledge, Trust, and Corporate Reputation Perception. Journal of Business Ethics, 154(4).

Kim, S., \& Ferguson, M.A.T. (2018) Dimensions of Effective CSR Communication Based on Public Expectations. Journal of Marketing Communications, 24(6).

Kooskora, M. (2010). Why to Talk About Ethical and Responsible Business. Giving Meaning to Ethics and Responsibility in Business. Ethical and Environmental Competence for Sustainable Development, $7(26)$.

112 Journal of Leadership Accountability and Ethics Vol. 18(1) 2021 
Murray, A. (2019, August 19). America's CEOs Seek a New Purpose for the Corporation. Forbes. Retrieved from https://fortune.com/longform/business-roundtable-ceos-corporations-purpose/

Nielsen, A.E., \& Thomsen, C. (2007). Reporting CSR - Why and How to say it? Corporate Communications: An International Journal, 12(1).

Nielsen, A.E., \& Thomsen, C. (2012). Corporate Social Responsibility (CSR) Management and Marketing Communication: Research Streams and Themes. Journal of Language and Communication in Business, 49.

Reputation Institute. (2018). How to build credibility through corporate responsibility. Retrieved from https://reputationinstitute.com

Rolfe, K. (2020, February) Has Sustainability Reporting Become Unsustainable? CIM Magazine, 15(1).

Styles, P. (2020). What is Greenwashing? The Importance of Maintaining Perspective in ESG

Communications. Retrieved from https://www.alpha-sense.com/insights/esg-communicationsgreenwashing

Think Parallax. (2019, June 19). The Formula for Communicating ESG (whitepaper). Retrieved from https://www.thinkparallax.com/Insight/formula-communicating-esg-white-paper/

Truesdale, P. (2018, February 1). Bad Apple? What is Missing from Apple's Corporate Responsibility Reporting? Corporate Citizenship. Retrieved from https://corporatecitizenship.com/2018/02/01/bad-apple-missing-apples-corporate-responsibility-reporting/

Valor, C. (2005). Corporate Social Responsibility and Corporate Citizenship: Towards Corporate Accountability. Business and Society Review, 110(2).

Welch, K., \& Yoon, A. (2020, June 2). Corporate Sustainability and Stock Returns: Evidence from Employee Satisfaction. Retrieved from https://ssrn.com/abstract=3616486 or http://dx.doi.org/10.2139/ssrn.3616486 